\title{
Seasonal and vertical variation in the $C: P$ ratio of suspended and settling seston of lakes
}

\author{
René Gächter \& Jürg Bloesch \\ Institute of Aquatic Sciences (EAWAG), Swiss Federal Institute of Technology (ETH), \\ Ueberlandstrasse 133, CH-8600 Dübendorf, Siwitzerland
}

Keywords: C: $\mathrm{P}$ ratio, seston, sedimentation, mineralization

\begin{abstract}
In the absence of field data it is often assumed that the $C: P$ ratio of the seston in lakes corresponds to the 'ideal' ratio of 106:1, reported by Redfield et al. (1963) for marine phytoplankton. However, we found out that in nearly all lakes studied $\mathrm{C}: \mathrm{P}$ ratios deviate systematically from this value especially during periods, when phosphorus is growth limiting. Thus, during summer the sestonic $\mathrm{C}: \mathrm{P}$ ratio generally exceeds 106 in the epilimnion, but decreases with depth in the hypolimnion. Possible mechanisms which may lead to these seasonal and spatial changes in the $\mathrm{C}: \mathrm{P}$ ratio are discussed.
\end{abstract}

\section{Introduction}

It is generally accepted that in most cases phosphorus is the key element in lake eutrophication. Therefore, knowledge of the links between phosphorus, carbon and oxygen cycling is of fundamental importance for understanding eutrophication and lake restoration. Information concerning the seasonal and spatial variation in the $C: P$ ratio of particulate matter provides information on the relative net uptake or release rates of these two major nutrients.

Redfield et al. (1963) introduced a general stoichiometric composition of marine phytoplankton (atomic $\mathrm{C}: \mathrm{N}: \mathrm{P}$ ratio $=106: 16: 1$ ). Based on such findings about average biomass composition Stumm \& Morgan $(1962,1981)$ postulated the following general equation for primary production and mineralization of biomass:

$$
\begin{aligned}
& 106 \mathrm{CO}_{2}+16 \mathrm{NO}_{3}^{-}+\mathrm{HPO}_{4}^{2-}+122 \mathrm{H}_{2} \mathrm{O}+18 \mathrm{H}^{+} \rightleftharpoons \\
& \mathrm{C}_{106} \mathrm{H}_{263} \mathrm{O}_{110} \mathrm{~N}_{16} \mathrm{P}_{1}+138 \mathrm{O}_{2}
\end{aligned}
$$

This equation is useful to describe 'average' pro-

Hydrobiologia 128, 193-200 (1985).

(C) Dr W. Junk Publishers, Dordrecht. Printed in the Netherlands. duction or mineralization, if large sets of data from various depths, seasons and waters are combined. However, this equation may fail to describe specific events correctly. For instance, it has recently been shown by Gächter \& Mares (1985) that in the hypolimnion of Lake Lucerne production of soluble reactive phosphorus (SRP) and oxygen consumption are not coupled according to equation (1). There is experimental evidence showing that sestonic particles do not release SRP by mineralization when settling, but rather take up SRP by physical-chemical sorption or biological activity (Gächter \& Mares, 1985; Currie \& Kalff, 1984). This uptake of phosphorus together with a simultaneous mineralization of organic carbon, leads to a decreasing $C: P$ ratio in settling particulate matter. Moreover, it is to be expected that during summer stratification, when algal growth becomes progressively more limited by depleting phosphorus supplies, the $C: P$ ratio of phytoplankton is higher than during winter turnover, when phosphorus is available in excess and primary production is limited by light.

The objective of this paper is to demonstrate the variability of sestonic $C: P$ stoichiometry in fresh- 
water lakes and to discuss possible reasons for deviations from the Redfield-ratio.

\section{Methods}

Particulate organic carbon (POC) was analyzed by taking 11 of lake water, sampled with Friedinger bottles, which was filtered through a Whatman $\mathrm{GF} / \mathrm{F}$ glass fibre filter (pore size $0.7 \mu \mathrm{m}$ ), preheated at $500{ }^{\circ} \mathrm{C}$. After filtration the filters were stored at $-20^{\circ} \mathrm{C}$, moistened after thawing with $0.1 \mathrm{ml}$ of $1 \mathrm{M}$ $\mathrm{HCl}$ to remove inorganic $\mathrm{C}$ (carbonates) and dried at $40^{\circ} \mathrm{C}$ before being analyzed in a HERAEUS CHN Analyzer (CHN Rapid).

Particulate phosphorus (PP) was determined as the difference between total $P$ concentration in unfiltered lake water and $0.45 \mu \mathrm{m}$ membrane filtered lake water. The samples were digested during 1 hour with $\mathrm{K}_{2} \mathrm{~S}_{2} \mathrm{O}_{8}$ at $120^{\circ} \mathrm{C}$ (Szabo, EAWAG manual, unpublished), and the phosphate (SRP) was measured with the molybdenum blue method (Vogler, 1965).

Seston was collected using cylindrical sediment traps (height $50 \mathrm{~cm}$, diameter $14 \mathrm{~cm}$ in Lake Lucerne; height $70 \mathrm{~cm}$, diameter $7 \mathrm{~cm}$ in Lakes Constance and Hallwil) over periods of 2-3 weeks positioned at various depths in the hypolimnion. After retrieval, the supernatant water of the traps was drained, and the remaining suspension homogeneously mixed. The Lake Lucerne samples were prefiltered through a $300 \mu \mathrm{m}$ plankton net to remove larger zooplankton. All POC and PP analyses of trapped material were performed directly on Whatman GF/F glass fibre filters and Sartorius CA membrane filters, respectively, using methods described above.

\section{Results}

Seasonal and vertical variation of $C: P$ ratios in the suspended seston of lakes

In several Swiss lakes, the atomic C: $\mathrm{P}$ ratio in suspended epilimnetic seston differed systematically from Redfield's 'ideal' C: $P$ ratio (Fig. 1). Primarily during summer stratification, but also during winter turnover, the $\mathrm{C}: \mathrm{P}$ ratios in surface layers $(0-5 \mathrm{~m})$ clearly exceeded 106 except in Lake Zürich (site Thalwil), where values scattered closely to the Redfield-ratio. These observations are in agreement with those made in Lake Ontario by Stadelmann \& Munawar (1974), and they are supported by high $\mathrm{C}: \mathrm{P}$ ratios determined in natural phytoplankton samples obtained from Lakes George (207: 1; Viner, 1970), Kinneret (235 to 645: 1; Serruya et al., 1976) and Lugano (209:1; Premazzi \& Marengo, 1982).

As indicated in Fig. 1, the $\mathrm{C}: \mathrm{P}$ ratio of suspended particulate matter just above lake bottoms is usually lower than in the surface waters (in 67 to $100 \%$ of all observations, in every lake). Fig. 2 shows this depth dependent decrease of the $\mathrm{C}: \mathrm{P}$ ratio in more detail for the period of highest epilimnetic $\mathrm{C}: \mathrm{P}$ ratios. Despite considerable variation it is evident that the $\mathrm{C}: \mathrm{P}$ ratio decline is greatest in the sub-surface layers. In the eutrophic lakes (Greifensee, Lake Zürich and Baldegg) the ratio decreased to 106 at about $10 \mathrm{~m}$, whereas in the oligotrophic to mesotrophic lakes (Walensee and Lake Lucerne) this required at least $60 \mathrm{~m}$. In extremely oligotrophic Lake Tahoe the atomic C: $\mathrm{P}$ ratios reached 385 at the surface and still exceeded 106 at $400 \mathrm{~m}$ (HolmHansen, 1972).

Seasonal and vertical variation of $C: P$ ratios in the entrapped seston of lakes

As shown for suspended material the composition of seston collected by sediment traps at the lower border of the epilimnion also differs systematically from the Redfield-ratio. Although all data sets showed considerable annual variation (examples in Fig. 3), the trends are evident when mean values for stratification and turnover periods are compared (Table 1). In all lakes, Lake Constance excepted, the $\mathrm{C}: \mathrm{P}$ ratios of entrapped epilimnetic material exceeded 106 during summer. During turnover these ratios were all lower than during stratification, with values well below 106 for Lakes Constance, Zug and Lucerne (1983, 1984).

In several lakes the $C: P$ ratio of trapped seston decreased with depth (Table 2), but this change appears less pronounced than found for suspended seston collected on filters (Fig. 2). No significant vertical differences occurred in Lake Hallwil and Lake Constance. However, these small changes or even the lack thereof are comprehensible, because the uppermost trap is usually situated below the 
$C: P$

by atoms / by weight

195

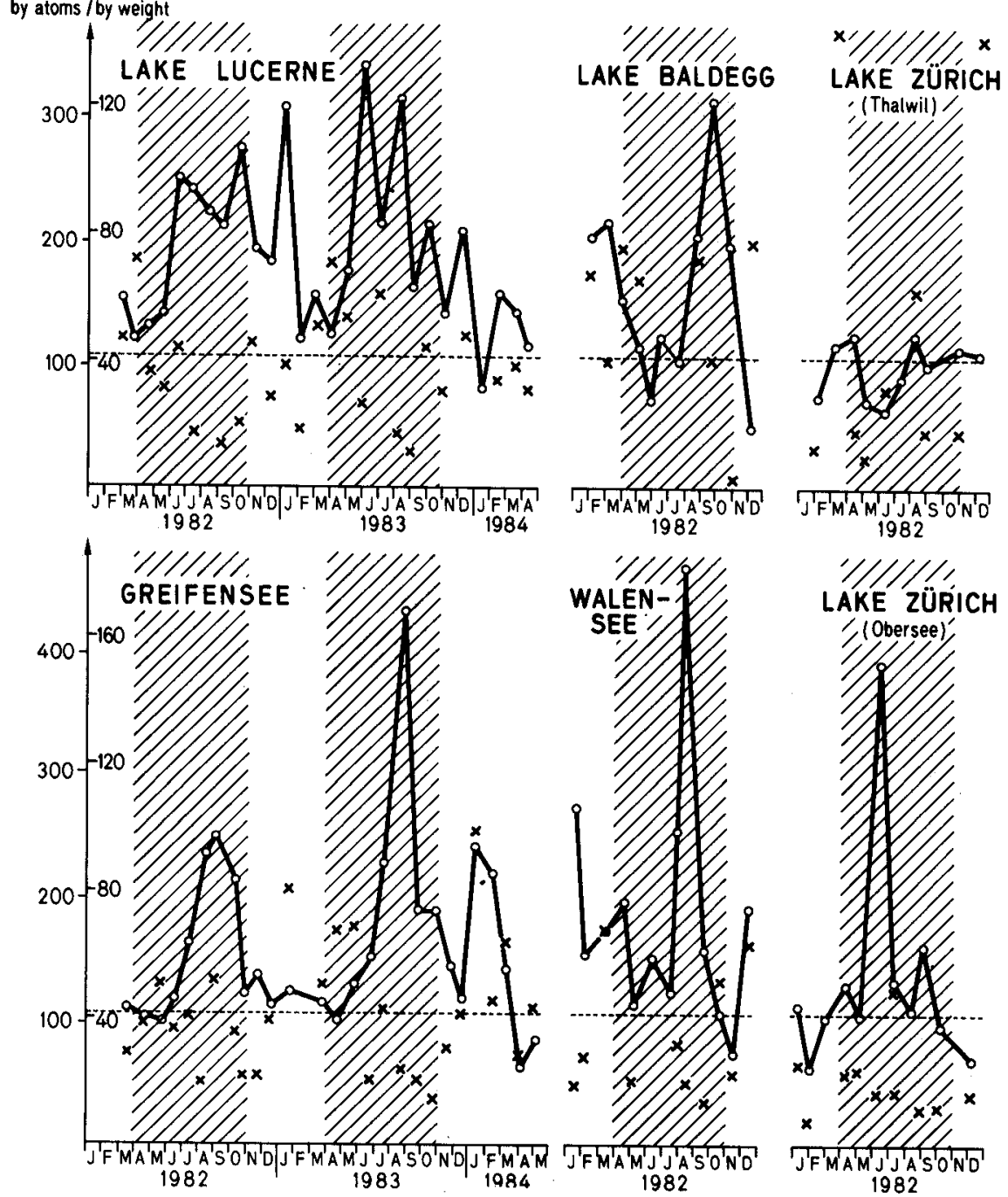

Fig. 1. Seasonal variations of sestonic C:P.ratios in the epilimnion (average value for the layer 0 to $5 \mathrm{~m}: \mathrm{O}_{-}-\mathrm{O}$ ) and above the lake bottom $(\mathrm{X})$. Shaded areas $=$ period of summer stratification.

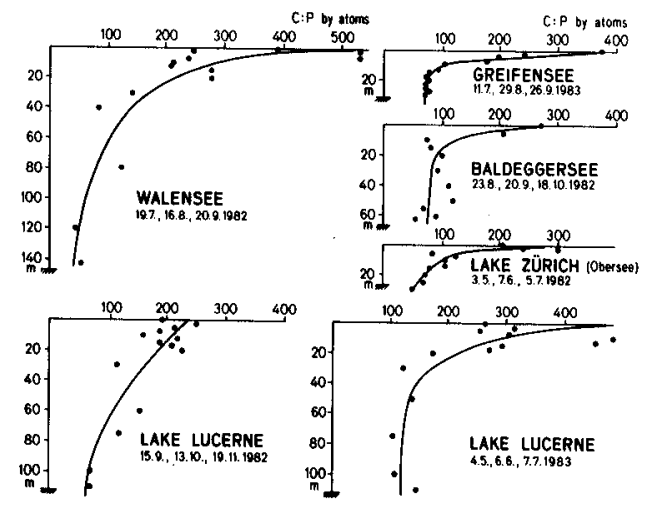

Fig. 2. Average $\mathrm{C}: \mathrm{P}$ profiles during the period of maximum epilimnetic $C: P$ ratios. epilimnion, and greatest vertical differences in suspended seston were observed within the epilimnion. Accordingly, the greatest dynamics in both particle formation and dissolution which lead to changes in chemical particle composition take place in the epiand metalimnion, whereas these processes are delayed or diminished in the hypolimnetic layers.

\section{Discussion}

The various data compilations presented demonstrate that in nearly all lakes studied the stoichio- 

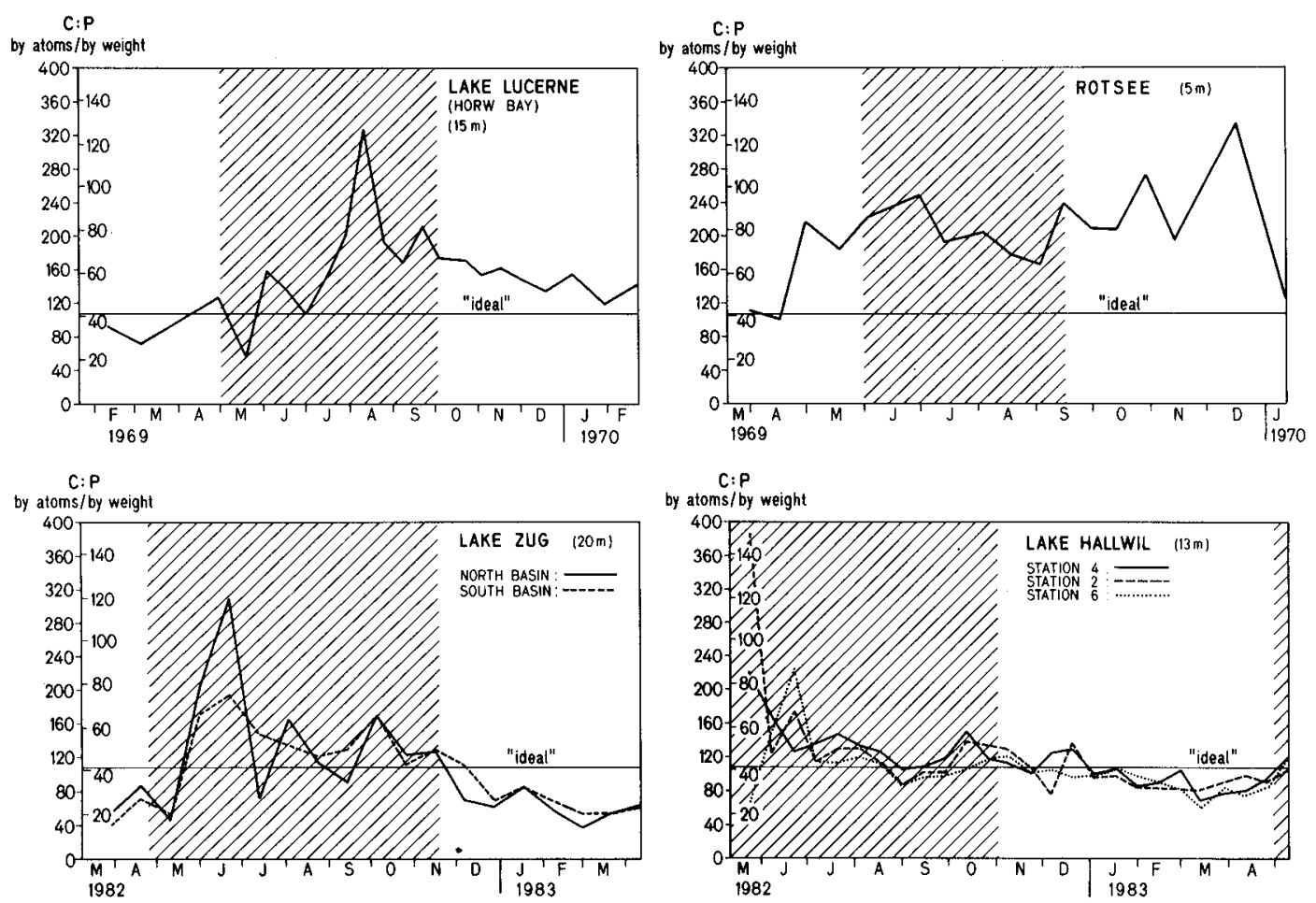

Fig. 3. C: P ratios of seston collected by sediment traps at the lower border of the epilimnion in several Swiss lakes. Shaded area $=$ period of summer stratification. Original data and data from Bloesch (1974) and Bloesch \& Sturm (1984).

Table 1. C:P ratios in seston collected by sediment traps at the lower border of the epilimnion of lakes. TP $=$ average total phosphorus $\left(\mathrm{mg} \cdot \mathrm{m}^{-3}\right)$ during spring turnover.

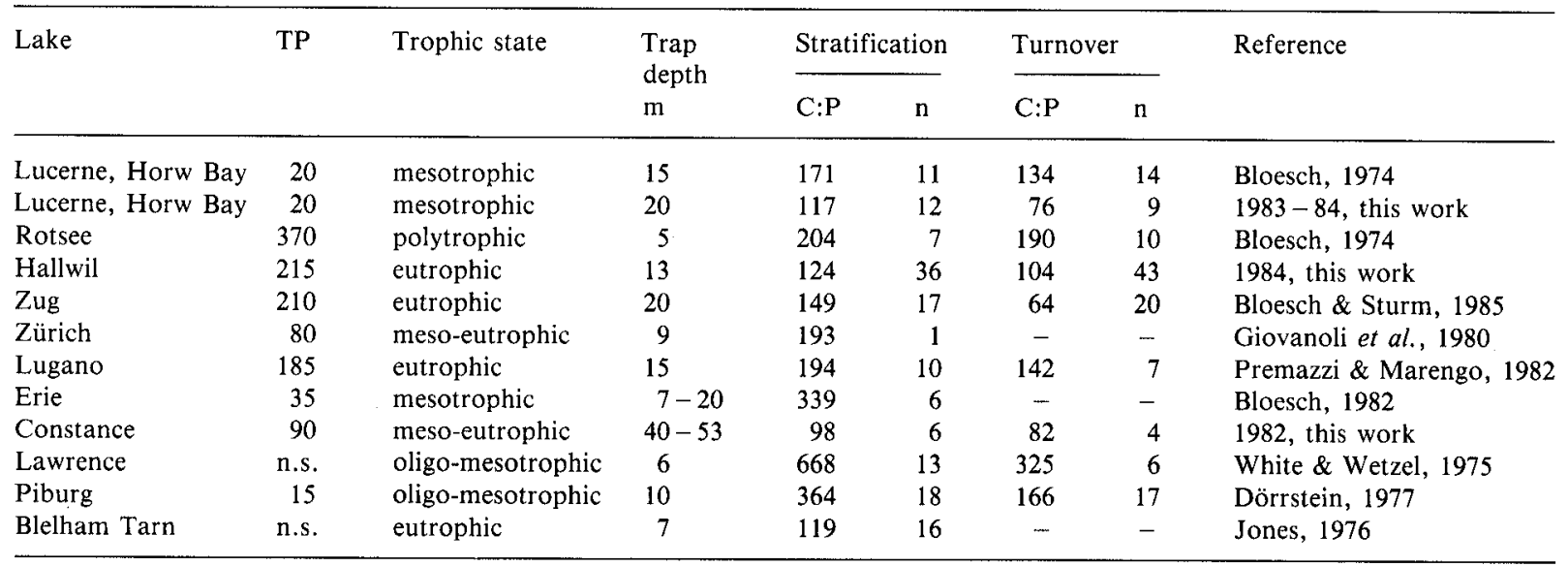

n.s. = not specified.

metric composition of suspended and entrapped seston does differ systematically from the 'ideal' composition of algal biomass proposed by Redfield et al. (1963). Especially during summer stratifica- tion, the $\mathrm{C}: \mathrm{P}$ ratios in the epilimnion mostly exceeded 106 considerably (Fig. 1, Table 1), and decreased with depth primarily in the epi- and metalimnion. Accordingly, chemical changes of seston 

Table 2. Vertical differences in the C:P ratios of seston collected by sediment traps at various lake depths. The lowest trap is positioned
between 1.5 and $12 \mathrm{~m}$ above lake bottom.

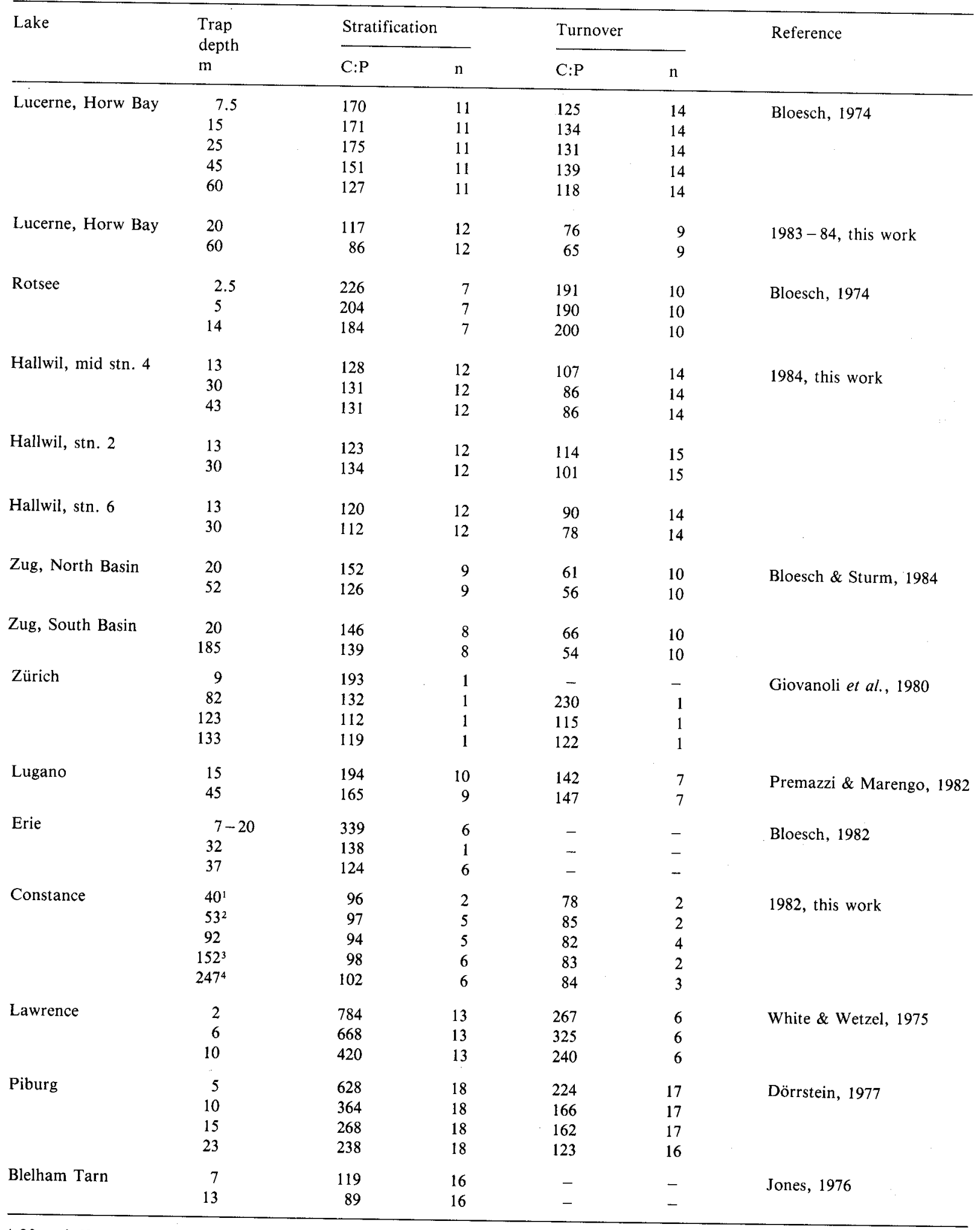

$120 \mathrm{~m}^{2} 60 \mathrm{~m}^{3} 120 \mathrm{~m}^{4} 210 \mathrm{~m}$ in the period of $18.6 .-8.7 .82$. 
associated with particle formation or dissolution occur mainly in the epi- and metalimnion and to a less extent in the hypolimnion.

Equation(1) postulates that algal growth requires $1 \mathrm{~mol} \mathrm{P}$ (as $\mathrm{HPO}_{4}^{2-}$ ) per $106 \mathrm{~mol} \mathrm{C}$ (as $\mathrm{CO}_{2}$ ). However, our data show that the biomass $\mathrm{C}: \mathrm{P}$ ratio increases during summer, when most likely phosphorus is growth-limiting. Thus, the nutrient supply seems to regulate the stoichiometric composition of biomass. This was experimentally shown by Goldman et al. (1979) for marine phytoplankton, by Uehlinger (1981) for Aphanizomenon flosaquae and confirmed by us for Chlamydomonas reinhardii (Fig. 4): During sufficient or excess $\mathrm{P}$ supply, the Chlamydomonas $\mathrm{C}: \mathrm{P}$ ratio was less than 106 , while growth rate was at the maximum of about $0.11 \mathrm{~h}^{-1}$. If the SRP supply was decreased, the $C: P$ ratio increased to values larger than 106 , and simultaneously growth rate decreased in proportion to the increasing $C: P$ ratio. From this we conclude in agreement with Goldman et al. (1979) that $\mathrm{C}: \mathrm{P}$ ratios close to the Redfield-value occur only when phytoplankton growth is not limited by phosphorus, a situation not typical for temperate freshwater lakes during summer. In phosphorus limited environments this nutrient is much more efficiently used by algae for biosynthesis of organic matter than it is assumed by equation(1), allowing the phytoplankton to synthesize much more than $106 \mathrm{~mol}$ of carbon per mol of phosphorus.

The $C: P$ ratio of seston could also be influenced by allochthonous particulate matter superimposing upon the biological processes of production and respiration in equation(1). Sturm et al. (1982) showed that at our sampling site in Lake Constance sedimentation was periodically dominated by inorganic allochthonous material from the alpine R hine River (Müller \& Quakernaat, 1969). Thus, the low

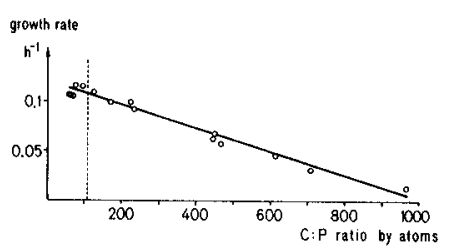

Fig. 4. Growth rate of Chlamydomonas reinhardit as a function of the $\mathrm{C}: \mathrm{P}$ ratio. Points represent average steady state conditions of several turbidostat and chemostat experiments conducted at $25^{\circ} \mathrm{C}$ and optimum light intensity.
$\mathrm{C}: \mathrm{P}$ ratios in this lake appear attributable to dilution of autochthonous organic matter by allochthonous P-containing inorganic material. This explains why the seston $C: P$ ratio never reached 106 , although it is unlikely that algal growth would not be phosphorus-limited in Lake Constance (Mohammed \& Müller, 1981).

Several events may contribute to the observed vertical decrease of the $C: P$ ratio during summer stratification: (1) Rhee \& Gotham (1981) showed that a temperature decrease from $20^{\circ} \mathrm{C}$ to $10^{\circ} \mathrm{C}$ resulted in a decrease in the $\mathrm{C}: \mathrm{P}$ ratio of $S$ cenedesmus cultures from 160 to 50 . However, these results cannot be transferred quantitatively to in situ conditions, since the suspended and collected seston consist mainly of detritus and not of healthy growing algae. Accordingly, the effect of temperature is likely of minor importance for the observed decrease of the C: $P$ ratio with increasing depth. (2) As demonstrated in Lake Erie (Bloesch, 1982) resuspension of bottom sediments with low $C: P$ ratio decreases the $C: P$ ratio of near bottom trap material. However, turbulent Lake Erie cannot be directly compared with our lakes featuring a comparably small wind fetch. Although resuspension of sediment particles with high water content occurs already at near bottom currents of a few $\mathrm{mm}$ to $\mathrm{cm} \cdot \mathrm{s}^{-1}$ (Terwindt, 1977; Rosa et al., 1983), our finding that the major decrease in the $\mathrm{C}: \mathrm{P}$ ratio occurred in the uppermost layers rather than close to the lake bottom (Fig. 2, Table 2) indicates that resuspension is not responsible to a great extent for the vertical decrease in the $\mathrm{C}: \mathrm{P}$ ratios of smaller lakes. (3) The results obtained can only be understood, if during decomposition of settling particles more carbon is mineralized than phosphorus is dissolved. There is strong evidence that settling material takes up SRP while decomposing, either through purely physical-chemical processes, such as sorption onto particle surfaces or precipitation, or through active SRP uptake by sinking algae or heterotrophic organisms colonizing on detritus (Currie \& Kalff, 1984; Gächter \& Mares, 1985; Stöckli, 1985). This together with the intensive mineralization of organic carbon within the epilimnion (Uehlinger et ao., 1984) hels explain the significant decrease of the $\mathrm{C}: \mathrm{P}$ ratio in the lower part of this layer.

In conclusion, our data show that the $\mathrm{C}: \mathrm{P}$ ratio of particulate matter in most freshwater lakes stu- 
died systematically deviate from the 'ideal' Redfield-ratio: The observed ratio is generally higher in the epilimnion during summer stratification, but decreasing with increasing sampling depth. Mechanisms leading to these deviations are most probably reduction of the phosphorus supply to algae during summer plus uptake of phosphorus by seston which respires organic carbon while settling through the trophogenic layer.

Dynamic lake models, used to predict the course of lake restoration, should be based on realistic parameters so as to improve their capabilities. Use of the inappropriate Redfield-stoichiometry to link carbon with phosphorus will result in the underestimation of primary production in phosphorus limited lakes. The commonly assumed $\mathrm{C}: \mathrm{P}$ ratio of about 106 appears to be the result of averaging large data sets from various lakes, depths and seasons but unsuitable for modelling the behavior of a specific lake.

\section{Acknowledgements}

We wish to thank H. Ambühl for providing unpublished data from Greifensee and Lake Lucerne; and $\mathrm{U}$. Zimmermann for making available samples from Walensee and Lake Zürich. The comments of E. Laczko, P. Santschi and D. E. Rathke in their reviews of the manuscript are appreciated.

\section{References}

Bloesch, J., 1974. Sedimentation und Phosphorhaushalt im Vierwaldstättersee (Horwer Bucht) und im Rotsee. Schweiz. Z. Hydrol. 36: 71-186.

Bloesch, J., 1982. Inshore-offshore sedimentation differences resulting from resuspension in the Eastern Basin of Lake Erie. Can. J. Fish. aquat. Sci. 39: 748-759.

Bloesch, J. \& M. Sturm, 1985. Settling flux and sinking velocities of particulate phosphorus (PP) and particulate organic carbon (POC) in Lake Zug, Switzerland. J. envir. Geol. (in press).

Currie, D. J. \& J. Kalff, 1984. The relative importance of bacterioplankton and phytoplankton in phosphorus uptake in freshwater. Limnol. Oceanogr. 29: 311-321.

Dörrstein, D., 1977. Sedimentation im Piburger See (Oetztal, Tirol). Ph. D. Thesis, Univ. Innsbruck, $118 \mathrm{pp}$.

Gächter, R. \& A. Mares, 1985. Does settling seston release soluble reactive phosphorus in the hypolimnion of lakes? Limnol. Oceanogr. 30: 366-373.
Giovanoli, R., R. Brütsch, D. Diem, G. Osman-Sigg \& L. Sigg, 1980. The composition of settling particles in Lake Zürich. Schweiz. Z. Hydrol. 42: 89-100.

Goldman, J. C., J. J. McCarthy \& D. G. Peavey, 1979. Growth rate influence on the chemical composition of phytoplankton in oceanic waters. Nature 279: 210-215.

Holm-Hansen, O., 1972. The distribution and chemical composition of particulate material in marine and fresh waters. Mem. Ist. ital. Idrobiol., Suppl. 29: 37-51.

Jones, J. G., 1976. The microbiology and decomposition of seston in open water and experimental enclosures in a productive lake. J. Ecol. 64: 241-278.

Mohammed, A. A.\& H. Müller, 1981. Zur Nährstofflimitierung des Phytoplanktons im Bodensee. Arch. Hydrobiol., Suppl. 59: 151-191.

Müller, G. \& J. Quakernaat, 1969. Diffractometric clay mineral analysis of recent sediments of Lake Constance (Central Europe). Contr. Miner. Petrol. 22: 268-275.

Premazzi, G. \& G. Marengo, 1982. Sedimentation rates in a Swiss-Italian lake measured with sedimentation traps. Hydrobiologia 92: 603-610.

Redfield, A. C., B. H. Ketchum \& F. A. Richards, 1963. The influence of organisms on the composition of seawater. In M. N. Hill (ed.), The sea, 2. Interscience Publishers, N.Y.: 26-77.

Rhee, G-Y. \& I. J. Gotham, 1981. The effect of environmental factors on phytoplankton growth: Temperature and the interactions of temperature with nutrient limitation. Limnol. Oceanogr. 26: 635-648.

Rosa, F., J. O. Nriagu, H. K. Wong \& N. M. Burns, 1983. Particulate flux at the bottom of Lake Ontario. Chemosphere 12: 1345-1354.

Serruya, C., M. Edelstein, U. Pollingher \& S. Serruya, 1974. Lake Kinneret sediments: Nutrient composition of the pore water and mud water exchanges. Limnol. Oceanogr. 19: 489-508.

Stadelmann, P. \& M. Munawar, 1974. Biomass parameters and primary production at a nearshore and a midlake"station of Lake Ontario during IFYGL. Proc. 17th Conf. Gt Lakes Res.: 109-119.

Stöckli, A, 1985. Die Rolle der Bakterien bei der Regeneration von Nährstoffen aus Algenexkreten und Autolyseprodukten - Experimente mit gekoppelten kontinuierlichen Kulturen. Ph. D. Thesis, ETH Zürich.

Stumm, W. \& J. J. Morgan, 1962. Stream pollution by algal nutrients. Trans. 12th annual Conf. sanit. Engng., Univ. Kansas: $16-26$.

Stumm, W. \& J. J. Morgan, 1981. Aquatic chemistry. An introduction emphasing chemical equilibria in natural waters. 2nd Edn. J. Wiley \& Sons, N.Y., 780 pp.

Sturm, M., U. Zeh, J. Müller, L. Sigg \& H.-H. Stabel, 1982. Schwebstoffuntersuchungen im Bodensee mit IntervallSedimentationsfallen. Eclog. geol. Helv. 75: 579-588.

Terwindt, J. H. J., 1977. Deposition, transportation and erosion of mud. In H. L. Golterman (ed.), Interactions between Sediments and Freshwater. Proc. int. Symp. Amsterdam, 6-10 September 1976: 19-24.

Uehlinger, U., 1981. Experimentelle Untersuchungen zur Autökologie von Aphanizomenon flos-aquae. Arch. Hydrobiol., Suppl. 60: 260-288. 
Uehlinger, U., P. Bossard, J. Bloesch, H. R. Bürgi \& H. Bührer, 1984. Ecological experiments in limnocorrals: Methodological problems and quantification of the epilimnetic phosphorus and carbon cycles. Verh. int. Ver. Limnol. 22: 163-171.

Viner, A. B., 1970. Ecological chemistry of a tropical African lake. Ph. D. Thesis, Univ. Lond., 192 pp.

Vogler, P., 1965. Beiträge zur Phosphatanalytik in der Limnologie. Il. Die Bestimmung des gelösten Orthophosphates.
Fortschr. Wasserchem. Grenzgeb. 2: 109-119.

White, W. S. \& R. G. Wetzel, 1975. Nitrogen, phosphorus, particulate and colloidal carbon content of sedimenting seston of a hard-water lake. Verh. int. Ver. Limnol, 19:330-339.

Received 26 October 1984; in revised form 23 April 1985; accepted 23 April 1985. 